\title{
Understanding the influence of digitalization on service firm business model design: a qualitative-empirical analysis
}

Submission to the Review of Managerial Science GIKA 2018 Special Issue (Revision 2)

Sven M. Laudien (corresponding author)

Macromedia University of Applied Sciences

Business School

Naststr. 11

D-70376 Stuttgart/Germany

phone: +49 $711280738-732$

email: sv.laudien@macromedia.de

\author{
Robin Pesch \\ University of Bayreuth \\ Chair for Strategic Management and Organization \\ Prieserstr. 2 \\ 95444 Bayreuth/Germany \\ phone: +49921554846 \\ email: robin.pesch@uni-bayreuth.de
}

Stuttgart, November $9^{\text {th }}, 2018$ 


\title{
Understanding the influence of digitalization on service firm business model design: a qualitative-empirical analysis
}

\begin{abstract}
This paper focuses on an analysis of how service firm digitalization is reflected in the business model design. We make use of an eclectic research approach combing insights from digitalization research, service firm research, and business model research. Against the background of nine in-depth case studies including 41 interviews and covering a three-yearperiod of time (2014 to 2017), we identify four digital service firm business model archetypes. Our findings show that implementing digital technologies and digitalizing business activities helps service firms to overcome traditional service-related business constraints. Digital technologies help to speed up service processes and to disentangle the still very often assumed linkage between human activities and services. Our data further reveals that service firms are enabled to enhance service availability and service efficiency in this realm. Interestingly, we observe no effect of ongoing digitalization on the firms' service-related knowledge base. Changes in the knowledge base only relate to digital knowledge.
\end{abstract}

Keywords: business model; digitalization, service firms, qualitative research.

JEL-Classification: L29; L80; M10; O33.

\section{Introduction}

Twenty-first century business relations are considerably shaped by the utilization of digital technologies (Newell and Marabelli 2015). Especially advances in information and communication technologies and a nearly unlimited availability of data allow firms to innovate business processes (McAfee and Brynjolfsson 2012). Data has recently become an important currency that firms can utilize to fuel their resource and knowledge base.

Employing digital solutions in the realm of service business goes along with major changes (Rai and Sambamurthy 2006): (1) Advancements in technologies that help to discover service needs are considerably changing the way how services can be offered and accessed. (2) Innovative ways of how services are integrated into products help service firms to be involved in value creation processes without being knowledgeable about the underlying product. (3) Technology-based changes allow for an enhanced and more specific interaction of business partners as well as a distinct control of the flow of information. This provides the opportunity for establishing new, even temporary ways of value co-creation. (4) Developments in process modeling make it possible to create a better response to demand side usage models. (5) Advancements in data mining help firms to boost business intelligence. This is very often reflected in an establishment of more nuanced service solutions. 
Although digitalization challenges cause a relevant research interest in general (Barkema et al. 2002; Biggiero 2006; Parviainen et al. 2017), we do by now not know very much about how especially service firms handle digitalization challenges as research on this topic is sparse. This depicts a major research gap taking into account that we face the rise of the service economy (Buera and Kaboski 2012). Against this background, this paper focuses on analyzing how the utilization of digital technologies influences the scope of action of service firms and the employed business model design. We ask:

How do service firm business model designs change due to digitalization and how does a possible change affect the service firm knowledge base?

Paying tribute to novelty and complexity of our research topic, we employ a qualitative research approach (Eisenhardt 1989; Yin 2012). The presented case data covers two points in time. This allows us to compare the firm's pre- or early-digitalization area business model designs with their recent business model designs and to present insights on the influence of digitalization on service firm business activities as well as accompanying structural or processual changes. We processed data using the well-established Gioia-methodology (Gioia et al. 2012).

Our findings show that implementing digital technologies and digitalizing business activities helps service firms to overcome traditional service-related business constraints. Digital technologies enable firms to speed up service processes and to disentangle the still very often assumed linkage between human activities and services. Our data further reveals that service firms can enhance service availability and service efficiency in this realm. Interestingly, we observe no effect of ongoing digitalization on the firms' service-related knowledge base. Changes in the knowledge base only relate to digital knowledge.

Our findings allow for a better understanding of how service firms can benefit from digitalization. We contribute to digitalization research and show in detail digitalization influences on business model change (Richter et al. 2017; Richter et al. 2015). We also enhance service management research (Niemand et al. 2017) by directly linking digitalization and service firm business model development. Our paper fosters a deeper linkage of digitalization, service firms, and business model research. 


\section{Theory background}

\subsection{Digitalization}

Follwing Negroponte (1995), digitalization can be understood as a process of converting analog into to digital information processing in a technical sense. However, this may reach a bit too short as this view mainly encompasses a technological perspective. We go a step further and understand digitalization as the application of digital technologies in a way that their application creates a measurable added value. This assumption is well-reflected in the definition of the socalled Internet of Things (IoT) (Ashton 2009) that is widely speaking the result of the application of digital technologies in a business context. In detail, the IoT is defined as " $[a]$ network of physical objects that contain embedded technology to communicate and sense or interact with their internal states or the external environment" (WEF 2015: 34). It is necessary to highlight that not the technologies itself determine the IoT. Important in this realm is the interconnectedness of smart objects that result from applying digital technologies (Miorandi et al. 2012).

The industrial usage of smart objects is addressed under the catchphrase Industrial Internet of Things (IIoT). According to first research results (see e.g. Atzori et al. 2010), the IIoT will enfold considerable impact on industrial production, but also especially on logistics and process management. Especially the latter points to the fact that the IIoT is not only of relevance in terms of enhancing efficiency, it also provides opportunities for designing completely new business models (Daugherty et al. 2015; Manyika et al. 2015). The IIoT may force firms to exploit completely new ways of how to create, deliver, and capture value as it is likely that the IIoT will change the rules of the game and therefore contribute to redefining competition (Daugherty et al. 2015). The IIoT is a breeding ground for the development and adaption of service firms' business models as new technologies allow for speeding up services and also for considerably changing the nature of service solutions.

\subsection{Services, service firms, and hybrid solutions}

Generally speaking, service firms provide intangible solutions while manufacturing firms focus on producing tangible outputs (Bruhn and Georgi 2006). Following Parasuraman et al. (1985), services can be characterized by four main criteria: intangibility, heterogeneity, inseparability, and perishability. These so-called IHIP-criteria are widely accepted in literature (see e.g. Sabine 
2010), although they are based on the idea that services and goods are basically different-a viewpoint that is challenged by an ongoing discussion (Grönroos 2006; Gummesson 2007; Vargo and Lusch 2004). Nevertheless, the IHIP-criteria are helpful to highlight differences between manufacturing firms and service firms. So we state that in contrast to manufacturing firms that focus on tangible outputs service firms offer solutions that lack the palpable quality of goods (Vargo and Lusch 2004). Furthermore, service firms are not as good as manufacturers able to standardize their offerings (Frambach et al. 1997). Service firms face in contrast to manufacturing firms the challenge of the simultaneous nature of service production and service consumption (Vargo and Lusch 2004). Additionally, service firms need to take into account the momentariness of their offerings (Vargo and Lusch 2004) which makes it impossible or at least compared to manufacturing firms very difficult to store their offerings.

In the 2000s, researchers (Grönroos 2006; Gummesson 2007) started to emphasize an increasing convergence of services and goods. This development somehow blurs the traditional boundaries between service firms and manufacturing firms as manufacturing firms today very often offer amendatory services to their product(s) (Roland 1998). This follows a trend of firms combining goods and services and developing so-called hybrid solutions that comprise tangible and intangible components (Ulaga and Reinartz 2011). Research defines these solutions as “... as products and services combined into innovative offerings..." (Shankar et al. 2009: 95). Hybrid solutions are likely to be of high importance in the realm of service firm digitalization.

\subsection{Business models and business model innovation}

The business model concept has evolved into a well-accepted framework of analysis that helps to uncover change processes as it employs a holistic perspective and takes firm internal and firm external aspects into account. However, the business model understanding in literature is quite diverse (see e.g. Amit and Zott 2001; Casadesus-Masanell and Ricart 2010; Osterwalder and Pigneur 2010; Teece 2010; Zott and Amit 2010). Consensus about the constitutive criteria of a business model is hard to find in literature (Spieth et al. 2014). Nevertheless, researchers agree that the business model concept can be employed as unit of analysis as it is distinct from strategy and operations and describes the logic how a firm creates, delivers, and captures value (Casadesus-Masanell and Zhu 2013; Demil et al. 2015; Teece 2010). Following Teece (2010: 17), we define the business model in this paper as "... the design or architecture of the value creation, delivery, and capture mechanisms." 
From a technology and innovation management perspective, business models are useful to commercialize the economic value of new technologies (Chesbrough and Rosenbloom 2002). It is therefore not surprising that early literature on business models and business model innovation particularly focused on analyzing how to exploit the potential of new information and communication technologies in terms of value generation (DaSilva and Trkman 2014). Therefore, researchers (e.g. Amit and Zott 2001; Mahadevan 2000; Timmers 1998) uncovered the nature of radically new business models that emerged due to new, web-based technologies.

As market competition seems to become harder year by year, firms face the challenge to create uniqueness. Chesbrough (2007: 12) emphasizes in the realm that innovation is "... not just about technology anymore." Firms face the challenge of innovationg the way how they create, deliver, and capture value (Casadesus-Masanell and Zhu 2013). In doing so, firms can, for instance, serve customer needs that are undiscovered by competitors (Markides 2006; Donald and Carol 2003). Nevertheless, with the rise of IIoT-related technology, the question whether the adoption of new technology calls for an adjustment or a radical change in the business model rises again (Loebbecke and Picot 2015).

\section{Methods}

Due to the fact that we deal with a still widely unexplored topic, we employ an inductive qualitative research design. Such a design is helpful and suitable for approaching new and complex topics (Graebner et al. 2012). Additionally, such a research approach allows for uncovering causal relations and therefore goes beyond a pure description of the analyzed phenomenon (Gartner and Birley 2002). We make use of a multiple-case study approach (Eisenhardt 1989) as such an approach is likely to provide accurate and valuable theoretical insights (Eisenhardt and Graebner 2007; Feagin et al. 1991) and helpful to gather rich, in-depth data (Bluhm et al. 2011; Yin 2012; 2009).

We decided for a purposeful sampling approach (Patton 2002) as we needed to create a coherent sample that ensures a certain richness of information (Denzin and Lincoln 2005). Therefore, we had to make sure that the firms under research are service firms affected by digitalizationa fact we evaluated based on firm websites and firm publications for each firm separately. We ended up with a sample of nine case firms. In detail, we applied the following criteria to our sample firms: (a) all firms are service firms that operate in a b-to-b setting. (b) Our sample firms are all SMEs with more than 10 and less than 100 employees to ensure comparability as 
well as to exclude firms that depend on more than one main business model-an aspect that is e.g. highlighted by Markides and Charitou (2004). (c) The firms under research are at the time of the first interview older than five and not older than ten years as we acknowledge the different characteristics of new ventures (Delmar and Shane 2003) and peculiarities of older firms. (d) All firms under research face digitalization challenges-a fact we made sure by conducting a pre-study investigation that evaluates information on firm websites and annual reports. Table 1 gives a short overview over the case firm and interview characteristics.

\begin{tabular}{|c|c|c|c|c|c|}
\hline $\begin{array}{l}\text { Case } \\
\text { firm }\end{array}$ & $\begin{array}{l}\text { Industry } \\
\text { (SIC) }\end{array}$ & $\begin{array}{c}\begin{array}{c}\text { Firm size } \\
\text { (no. of } \\
\text { employees) }\end{array} \\
\end{array}$ & $\begin{array}{c}\text { Founding } \\
\text { year }\end{array}$ & Core business & $\begin{array}{c}\text { No. of } \\
\text { interviews }\end{array}$ \\
\hline 1 & $\begin{array}{l}8711 \\
\text { engineering } \\
\text { services }\end{array}$ & $11-50$ & 2009 & $\begin{array}{l}\text { automation engineering focus, } \\
\text { additionally development of software } \\
\text { solutions }\end{array}$ & 3 \\
\hline 2 & $\begin{array}{c}8721 \\
\text { accounting, } \\
\text { auditing, and } \\
\text { bookkeeping } \\
\text { services }\end{array}$ & $11-50$ & 2008 & $\begin{array}{l}\text { focus on tax accounting, specialized in } \\
\text { international taxation }\end{array}$ & 4 \\
\hline 3 & $\begin{array}{c}8748 \\
\text { business } \\
\text { consulting } \\
\text { services, not } \\
\text { elsewhere } \\
\text { classified } \\
\end{array}$ & $11-50$ & 2007 & $\begin{array}{l}\text { focus on IT and management } \\
\text { consulting; specialized in service- } \\
\text { related IT }\end{array}$ & 2 \\
\hline 4 & $\begin{array}{c}7389 \\
\text { business } \\
\text { services not } \\
\text { elsewhere } \\
\text { classified } \\
\end{array}$ & $51-100$ & 2011 & $\begin{array}{l}\text { facility management firm only working } \\
\text { for business customers }\end{array}$ & 5 \\
\hline 5 & $\begin{array}{c}7371 \\
\text { computer } \\
\text { programming } \\
\text { services }\end{array}$ & $11-50$ & 2008 & $\begin{array}{l}\text { focus on industrial software solutions; } \\
\text { firm is specialized in creating highly } \\
\text { customized solutions }\end{array}$ & 7 \\
\hline 6 & $\begin{array}{c}7389 \\
\text { business } \\
\text { services not } \\
\text { elsewhere } \\
\text { classified }\end{array}$ & $11-50$ & 2005 & $\begin{array}{l}\text { operating in the field of consulting and } \\
\text { project management related to cargo } \\
\text { handling }\end{array}$ & 5 \\
\hline 7 & $\begin{array}{c}8748 \\
\text { business } \\
\text { consulting } \\
\text { services, not } \\
\text { elsewhere } \\
\text { classified } \\
\end{array}$ & $11-50$ & 2007 & $\begin{array}{l}\text { focus on logistics operations, } \\
\text { specialized in handling high-risk cargo }\end{array}$ & 4 \\
\hline 8 & $\begin{array}{c}8711 \\
\text { engineering } \\
\text { services }\end{array}$ & $11-50$ & 2011 & $\begin{array}{l}\text { special focus on chemical engineering; } \\
\text { specialized in healthcare products }\end{array}$ & 6 \\
\hline
\end{tabular}




\begin{tabular}{c|c|c|c|c|l}
\hline 9 & $\begin{array}{c}7389 \\
\text { business } \\
\text { services not } \\
\text { elsewhere } \\
\text { classified }\end{array}$ & $51-100$ & 2007 & $\begin{array}{l}\text { developer of online payment systems, } \\
\text { high degree of linkages with customers }\end{array}$ & 3 \\
\hline
\end{tabular}

Table 1: Case firm characterization (own illustration).

The main data source of our study are interviews with the CEOs of the firms under research as well as with additional firm representatives that are responsible for introducing or running digitalization-based operations. The interviews that lasted about 1.5 hours on average took place between October 2014 and November 2017 at the firm premise. We approached each firm at two points in time with a time lag of about three years between the interviews. We conducted a total of 41 interviews in all firms at all points in time. We decided for focusing at CEOs as a primary data source as they are not only knowledgeable about the firm's digitalization strategy and related business model changes, but also have the formal authority to report these issues. The additional interviews helped us to enhance the richness of information and were also helpful for not running into key informant bias issues. We recorded and transcribed all interviews carefully and sent the transcripts back to the interviewed persons for verification to ensure data accuracy. We designed the interviews as open interviews and started all interviews with the question how the firm representatives perceive the influence of digitalization on business operations.

As we acknowledge the importance of prior insights, we make use of a so-called prior informed approach (Strauss and Corbin 1998). Following our initial question, we asked the interview partners to tell us about important actions that were taken to deal with digitalization challenges, to estimate the importance of the action, and to position it on timeline predefined by the existence of the firm (Clausen 1998). The timeline was checked and enhanced during the second round of interviews taking place in 2017. To increase the validity of our data, we additionally included data from sources such as firm websites, annual reports or press coverage of our study (Yin 2012).

We analyzed data by making use of content analysis techniques as suggested by Gioia et al. (2012). In line with Strauss and Corbin (1998) who employ an iterative open coding technique, Gioia et al. (20012) suggest a stepwise approach in which a variety of informant terms, codes, or categories, which emerge in an early stage of the data analysis process, are distilled into more abstract themes and aggregate dimensions. We employed a two-step approach: in the first step, two researchers (one present at the interview, one independent and not familiar with the data) independently coded the data. The results of the individual coding processes were collated in 
charts, discussed, and combined. There results of the individual coding were in no case contradictory. In a second step, we further analyzed the data while making use of the constant comparison method. This method involves an iterative reviewing of data with emerging categories and concepts (Bansal and Corley 2012). These categories and concepts that came up during the analysis of the first interview block conducted in 2014 were shaped and redefined taking into account the information gathered during the second interview block conducted in 2017. The identified effects of digitalization on service firm business model designs and the identified shift from 2014 to 2017 are presented in the next section.

\section{Results}

Our data allows for the identification of four archetypes of digitalized service firm business models. These archetypes are presented as matrix in table 2 . 


\begin{tabular}{|c|c|c|}
\hline $\begin{array}{l}\text { Business model } \\
\text { archetype }\end{array}$ & Description & Exemplary quotes \\
\hline $\begin{array}{l}\text { Digital beginner } \\
\text { service firm } \\
\text { business model (1) }\end{array}$ & $\begin{array}{l}\text { value creation (vc) } \\
\text { - } \text { digital technologies do not contribute to } \\
\text { value generation in a relevant way } \\
\text { - } \text { utilization of digital technologies only as } \\
\text { replacement for analogue technologies, } \\
\text { no process change } \\
\text { value delivery (vd) } \\
\text { - traditional value delivery, customer and } \\
\text { service offering come together at a } \\
\text { physical point of sale } \\
\text { - especially no approaches to overcome } \\
\text { the traditional inseparability of service } \\
\text { production and service consumption } \\
\text { value capture (vcap) } \\
\text { - no special focus on digital payment } \\
\text { systems such as e.g. paypal, traditional } \\
\text { payment dominates; pay per transaction } \\
\text { - no utilization of customer data to } \\
\text { enhance value capture }\end{array}$ & $\begin{array}{l}\text { - "We are digital-but digital technologies } \\
\text { do not change anything. See- it is not } \\
\text { important whether an order comes via } \\
\text { email or via mail." (vc) (CEO of case } \\
\text { firm 6) } \\
\text { - "Service is about meeting customers in } \\
\text { our office-digital technologies may } \\
\text { make things easier, but they do not } \\
\text { change the nature of our business." (vd) } \\
\text { (CDO of case firm 2) } \\
\text { - "Our business is about cash-not about } \\
\text { bitcoins!" (vcap) (CEO of case firm 1) } \\
\text { - "We love our customers and protect their } \\
\text { data well-we do not sell or utilize it-by } \\
\text { no means." (vcap) (Middle manager of } \\
\text { case firm 2) }\end{array}$ \\
\hline $\begin{array}{l}\text { Customization- } \\
\text { focused service } \\
\text { firm digital } \\
\text { business model (2) }\end{array}$ & $\begin{array}{l}\text { value creation (vc) } \\
\text { - value creation in interaction with } \\
\text { customers, "value co-creation" } \\
\text { - } \text { specific focus on customer needs, } \\
\text { utilization of digital technologies to } \\
\text { identify customer needs and wishes } \\
\text { value delivery (vd) } \\
\text { - following customer preferences, } \\
\text { dominance of online delivery } \\
\text { - focus on just-in-time value delivery; } \\
\text { service offerings are flexibly brought to } \\
\text { the customer; value delivery at the } \\
\text { customer premise } \\
\text { value capture (vcap) } \\
\text { - no special focus on digital payment } \\
\text { systems such as e.g. paypal but general } \\
\text { openness to those systems; pay per } \\
\text { transaction } \\
\text { - first approaches to utilize customer data } \\
\text { to enhance value capture; data is used in } \\
\text { accordance with privacy regulations }\end{array}$ & $\begin{array}{l}\text { - "Our business is about our customers- } \\
\text { we want and need to fulfil their needs in } \\
\text { the best possible way!" (vc) } \\
\text { (Representative of case firm 6) } \\
\text { - "We deliver our offerings in the way our } \\
\text { customers want it. We are flexible as } \\
\text { digital technologies allow flexibility } \\
\text { nowadays." (vd) (CEO of case firm 4) } \\
\text { "Customers can pay in the way they } \\
\text { want-we take any payment. Data is also } \\
\text { a form of additional payment for us-as } \\
\text { long as the customer gives us the } \\
\text { permission to use the data." (vcap) } \\
\text { (CDO of case firm 8) }\end{array}$ \\
\hline
\end{tabular}




\section{value creation (vc)}

- utilization of digital technologies to bridge distances; partner integration

- expertise for every challenge is flexibly integrated into value creation processes

value delivery (vd)

- complete online delivery of value, digital technologies build the necessary groundwork for bringing value to the customer

Distance-bridging service firm digital business model (3)

Full scale digital
service firm
business model (4)

value capture (vcap)

- no special focus on digital payment systems such as e.g. paypal but general openness to those systems; pay per transaction

- full utilization of customer data to enhance value capture; no or only very little data protection
- "Digital technologies have allowed us to enhance our scope of action and to work together with partners from all over the world." (vc) (Representative of case firm 9)

- "Our scope is the world-we deliver online and do not even think about offline value delivery. Digital technologies luckily allow to go this way." (vd) (CDO of case firm 5)

- "Electronic payment is not easy in our business-we deal with cultures where money is still mainly cash. We accept that-and try to benefit from information our customers give us." (vcap) (CEO of case firm 3).

\section{value creation (vc)}

- full digital value creation; no standing team of employees, utilization of freelancers to enhance flexibility; machine-to-machine interaction

- digital interaction; vanishing roles of customer and supplier, true co-creation and very often simultaneous work on the same project by both parties that is made possible by digital technologies

value delivery(vd)

- online value delivery, offline delivery not part of the business

- digitalization as booster of flexibility to satisfy customer needs

value capture(vc)

- only online payment, very often automatic systems

- unlimited utilization of customer data in the realm of value creation.
- "This is the $21^{\text {st }}$ century! Why not making use of its technological opportunities? We are flexibleinteraction does not even need humans, machines can act on their own in many cases. The result counts for us." (vc) (CEO of case firm 1).

- "We approach our customers only online. This is easier and more convenient and saves costs!" (vd) (CEO of case firm 5)

- "Online payment is our business-why should we go for a different way? We are experts in this form of payment-and we know about the benefits of collecting customer data!" (vcap) (CEO of case firm 4)

Table 2: Archetypes of service firm digital business models (own illustration).

Taking a deeper look at the identified archetypes, we observe two very interesting issues: (1) service firms employ digital technologies for basically different purposes. Apart from efficiency-seeking motives (archetype 1), especially a need for better matching customer needs to be able to survive in the market competition (archetype 2), an enhancement of the geographic 
firm scope of action (archetype 3) and the need for a flexible and fast response to market needs (archetype 4) are reason for service firms to employ digital technologies and to transform their traditional business model.

Second, we observe a change between 2014 and 2017 in the utilization of the identified archetypes. While in 2014 the case firms mainly focused on the first two archetypes, further technology advancements between 2014 and 2017 fostered the emergence of the last two archetypes. Interestingly, this is not a replacement logic; we do not observe a "one-size-fits-all" kind of a digital service firm business model. Our data reveals that all case firms started with archetype (1); but between 2014 and 2017 we observe no change from business model archetype 2, 3, or 4 in a different archetype. This points to a basic stability of digitalization strategies which is reflected in the utilization of business model designs that are quite lasting.

Third, we observe that the nature of services does surprisingly not change in the realm of digitalization. Digital service offerings do not differ from traditional service offerings with regard to the service aspect. The change digitalization makes to service offerings is related to the way how a specific service is created and/or delivered, not to the service itself. As a result, our data shows that the firms under research considerably enhance their digital knowledge base while confronted with digitalization. However, we do not observe a change in the service knowledge base.

\section{Discussion and Conclusion}

Our data shows that digitalization imposes an effect on the design of service firm business models. Interestingly, the observed effect is not as radical as expected. Service firms seem to make use of digitalization as means to improve traditional ways of value creation, value delivery, and value capture. Yes-service firms slightly adjust their strategies and following their 
business models to be in line with digitalization requirements. Interestingly, this adjustment firm digital business models are relatively stable-a finding that is supported by Doz and Kosonen (2010) who emphasize the importance of strategic rigidity as barrier to business model change. However, our finding stands in sharp contrast to literature discussing strategic renewal (e.g. Agarwal and Helfat 2009) as this literature stream emphasizes the processual, dynamic nature of strategic renewal. Looking at the business model level, McGrath (2010) as well as Teece (2010) discuss the need for firms for adjusting their business model to create a fit with changing ecosystem conditions. However, also in this case the processual and dynamic aspect is emphasized. Our findings open up the question whether service firm digitalization can really be viewed as a continuous process-an aspect that deserves further research attention.

The portrayed service firm digital business model archetypes characterize different approaches to digitalization on a firm level. Our data shows that digital knowledge-related limitations at least at the beginning seem to influence how service firms approach digitalization. This finding can be explained by referring to literature that emphasizes cognitive constraints as a serious barrier to strategic as well as business model change (Sosna et al. 2010). It is supported by the fact that we do not observe a change of service knowledge over the three years of our study, but only an enhancement of digital knowledge that fuels initial firm knowledge deficits.

Naturally, we have to acknowledge shortcomings that go along with the employed research approach: (a) digitalization is by now mainly understood as complex technological phenomenon; uncovering its managerial consequences calls for simplification; (b) our sample size is limited; however, the number of nine cases and 41 interviews considerably exceeds suggestions by Yin (2012) or Eisenhardt (1989) and can be considered a sold empirical base; (c) our findings are strictly limited to our sample, they are not generalizable which is inherent in qualitative research. 
Our results help service firms to better deal with digitalization-triggered change necessities as

we uncover factors that determine the design of successful service firm digital business models reflected in four archetypes of service firm digital business models. We provide a new perspective on service firm digital business models and emphasize the uniqueness of service firm digital business models and the way how they are established. Our research shows how service firms can overcome traditional service-related constraints by means of digitalization. Therefore, our paper coevally offers contributions to digitalization literature, service management literature, and business model literature. We provide a holistic perspective on the role digitalization plays in the realm of the ongoing service-focused economic transformationan aspect that has as far as we know not properly been addressed before. 


\section{References}

Agarwal R, Helfat CE (2009) Strategic renewal of organizations. Organ Sci 20:281-293

Amit R, Zott C (2001) Value creation in e- business. Strateg Manage J 22:493-520

Ashton K (2009) The 'Internet of Things' thing. RFID Journal

Atzori L, Iera A, Morabito G (2010) The Internet of Things: A survey. Comput Netw $54: 2787-2805$

Bansal P, Corley K (2012) Publishing in AMJ - Part 7: What's Different about Qualitative Research? Acad Manage J 55:509-513

Barkema HG, Baum JAC, Mannix EA (2002) Management challenges in a new time. Acad Manage J 45:916-930

Biggiero L (2006) Industrial and knowledge relocation strategies under the challenges of globalization and digitalization: the move of small and medium enterprises among territorial systems. Entrep Region Dev 18:443-471

Bluhm DJ, Harman W, Lee TW, Mitchell TR (2011) Qualitative research in management: A decade of progress. J Manage Stude 48:1866-1891

Bruhn M, Georgi D (2006) Services Marketing. Pearson Education Harlow

Buera FJ, Kaboski JP (2012) The rise of the service economy. Amer Econ Rev 102:2540-2569

Casadesus-Masanell R, Ricart JE (2010) From strategy to business models and onto tactics. Long Range Plann 43:195-215

Casadesus-Masanell R, Zhu F (2013) Business model innovation and competitive imitation: The case of sponsor-based business models. Strateg Manage J 34:464-482

Chesbrough H, Rosenbloom RS (2002) The role of the business model in capturing value from innovation: evidence from Xerox Corporation's technology spin- off companies. Ind Corp Change 11:529-555

Chesbrough HW (2007) Business model innovation: It's not just about technology anymore. Strategy \& Leadership 35:12-17

Clausen JA (1998) Life reviews and life stories. In: Giele JZ, Elder GH (eds) Methods of Life Course Research: Qualitative and Quantitative Approaches Sage, Thousand Oaks, pp $189-212$

DaSilva CM, Trkman P (2014) Business model: What it is and what it is not. Long Range Plann 47:379-389

Daugherty P, Banerjee P, Negm W, Alter EA (2015) Driving unconventional growth through the industrial internet of things. Accenture, 
Delmar F, Shane S (2003) Does business planning facilitate the development of new ventures? Strateg Manage J 24:1165-1185

Demil B, Lecocq X, Ricart JE, Zott C (2015) Introduction to the SEJ special issue on business models: business models within the domain of strategic entrepreneurship. Strateg Entrep J 9:1-11

Denzin NK, Lincoln YS (2005) The SAGE Handbook of Qualitative Research. Third Edition edn. Sage Publications,

Donald M, Carol C (2003) The ultimate competitive advantage of continuing business model innovation. J Bus Strategy 24:15-21

Doz YL, Kosonen M (2010) Embedding strategic agility: A leadership agenda for accelerating business model renewal. Long Range Plann 43:370-382

Eisenhardt KM (1989) Building theories from case study research. Acad Manage Rev 14:532550

Eisenhardt KM, Graebner ME (2007) Theory building from cases: opportunities and challenges. Acad Manage J 50:25-32

Feagin JR, Orum AM, Sjoberg G (1991) A Case for the Case Study. UNC Press Books, Chapel Hill, NC

Frambach RT, Wels-Lips I, Gündlach A (1997) Proactive product service strategies: An application in the European health market. Ind Market Manag 26:341-352

Gartner WB, Birley S (2002) Introduction to the special issue on qualitative methods in entrepreneurship research. J Bus Venturing 17:387-395

Gioia DA, Corley KG, Hamilton AL (2012) Seeking qualitative rigor in inductive research: notes on the Gioia methodology. Organ Res Methods 16:15-31

Graebner ME, Martin JA, Roundy PT (2012) Qualitative data: Cooking without a recipe. Strateg Organ 10:276-284

Grönroos C (2006) Adopting a service logic for marketing. Marketing Theor 6:317-333

Gummesson E (2007) Exit service marketing-Enter service marketing. Journal of Customer Behavior 6:113-141

Loebbecke C, Picot A (2015) Reflections on societal and business model transformation arising from digitization and big data analytics: A research agenda. J Strategic Inf Syst 24:149157

Mahadevan B (2000) Business models for Internet based E Commerce: Ananatomy. Calif Manage Rev 42:55-69 
Manyika J, Chui M, Bisson P, Woetzel J, Dobbs R, Bughin J, Aharon D (2015) The internet of things: Mapping the value beyond the hype. Mc Kinsey Global Institute, Seoul

Markides C (2006) Disruptive innovation: in need of better theory*. J Prod Innovat Manag 23:19-25

Markides C, Charitou D (2004) Competing with dual business models: A contingency approach. Acad Manage Exec (1993-2005) 18:22-36

McAfee A, Brynjolfsson E (2012) Big data: The management revolution. Harvard Bus Rev 90:60-68

McGrath RG (2010) Business Models: A Discovery Driven Approach. Long Range Plann $43: 247-261$

Miorandi D, Sicari S, De Pellegrini F, Chlamtac I (2012) Internet of things: Vision, applications and research challenges. Ad Hoc Netw 10:1497-1516

Negroponte N (1995) Being Digital, Vintage Books. London Neustadt, RM (1985)`Electronic Politics' In Forester, T(ed) The Information Technology

Newell S, Marabelli M (2015) Strategic opportunities (and challenges) of algorithmic decisionmaking: A call for action on the long-term societal effects of 'datification'. J Strategic Inf Syst 24:3-14

Niemand T, Rigtering C, Kallmünzer A, Kraus S, Matijas S Entrepreneurial orientation in the financial service industry: A contigengcy approach. In: 25th European Conference on Information Systems (ECIS),, Guimarães, Portugal June 5-10, 2017 2017. pp 1081-1096

Osterwalder A, Pigneur Y (2010) Business Model Generation: A Handbook for Visionaries, Game Changers, and Challengers. Wiley, Indianapolis

Parasuraman A, Zeithaml VA, Berry LL (1985) Conceptual model of service quality and its implications for future research. J Marketing 49:41-50

Parviainen P, Tihinen M, Kääriäinen J, Teppola S (2017) Tackling the digitalization challenge: how to benefit from digitalization in practice. International Journal of Information Systems and Project Management 5:63-77

Patton MQ (2002) Qualitative Research and Evaluation Methods. 3 edn. Sage Publications Ltd, Rai A, Sambamurthy V (2006) Editorial notes: the growth of interest in services management: opportunities for information systems scholars. Inform Syst Research 17:327-331

Richter C, Kraus S, Brem A, Durst S, Giselbrecht C (2017) Digital entrepreneurship: Innovative business models for the sharing economy. Creat Innov Manag 26:300-310 
Richter C, Kraus S, Syrjä P (2015) The shareconomy as a precursor for digital entrepreneurship business models. International Journal of Entrepreneurship and Small Business 25:1835

Roland R (1998) What is the domain of service research? J Serv Res-US 1:107-107

Sabine M (2010) Characteristics of services-a new approach uncovers their value. Journal Serv Mark 24:359-368

Shankar V, Berry L, Dotzel T (2009) A Practical Guide to Combining Products and Services. Harvard Bus Rev 87:94-99

Sosna M, Trevinyo-Rodríguez RN, Velamuri SR (2010) Business model innovation through trial-and-error learning: The Naturhouse case. Long Range Plann 43:383-407

Spieth P, Schneckenberg D, Ricart JE (2014) Business model innovation-state of the art and future challenges for the field. R\&D Manage 44:237-247

Strauss A, Corbin J (1998) Basics of Qualitative Research: Techniques and Procedures for Developing Grounded Theory. 2 edn. Sage Publications, Thousand Oaks

Teece DJ (2010) Business models, business strategy and innovation. Long Range Plann 43:172194

Timmers P (1998) Business models for electronic markets. Electron Mark 8:3-8

Ulaga W, Reinartz WJ (2011) Hybrid offerings: How manufacturing firms combine goods and services successfully. J Marketing 75:5-23

Vargo SL, Lusch RF (2004) The four service marketing myths: Remnants of a goods-based, manufacturing model. J Serv Res-US 6:324-335

WEF (2015) Industrial Internet of Things: unleashing the potential of connected products and $\begin{array}{llll}\text { services. World Economic } & \text { Fo-rum Agenda. }\end{array}$ http://www3.weforum.org/docs/WEFUSA_IndustrialInternet_Report2015.pdf. Accessed 02.032018

Yin RK (2009) Case study research: Design and Methods. Sage Publications, Thousand Oaks

Yin RK (2012) Applications of case study research. 5 edn. Sage publications, Thousand Oaks, CA

Zott C, Amit R (2010) Business model design: an activity system perspective. Long Range Plann 43:216-226 